of the whole body, being devoid of pigment, is of a silverywhite colour, though often when viewed in bulk a pale-straw hue is apparent. But the most striking change is seen in the eyes. There the rays of light diffuse through iris as well as pupi], giving to the latter the red appearance familiar through the mirror of the ophthalmoscope, and to the former a rose-pink hue derived from the vessels of the choroid and of the iris itself. The photophobia which results from the relative non-absorption of the rays of light leads to a babit in the albino of continually screwing together his lids in order to admit only the minimum of rays essential to sight, and this, in conjunction with the characters already mentioned, forms a picture which makes what $\mathrm{I}$ am in the habit of calling the albinotio facies a distinctly characteristic one.

Probably the varieties of this condition are more numerous than we suspect. Among the coloured races, in whom the condition is much more common, a piebald variety is ofter found for which the name of partial albinism seems as good as any. When one of these patches of congenital leucoderma exists in the situation from which the eyes are developed true albinotic eyes are found as a result, and similarly when a patch involves the scalp or other portion of the hair system the hair in that situation partakes of all the characters of true albinotic hair. For some time I have been strongly of opinion that a like condition occurs amon Europeans, only masked by the already white colour of the great part of their skin. In some cases observed the hair has been pigmented, as in that described by Folker, while the rest of the body showed the usual features associated with albinism; in others, again, the only indications of albinism at all have been the characters of the eyes, which were in every respect those of an albino. In still other cases eyes and skin have been apparently normal, while the hair of the scalp has been congenitally white. I have never been able to satisfy myself that in these instances there were any corresponding differences to be noted on the skin, but the condition is bound to include many varieties, and I should be greatly obliged if physicians who have the opportunity of doing so would kindly endeavour to come to decision on this interesting point.

I have thus briefly described the typical appearances presented by an albino, and some of the varieties which have been observed because it is important in examining such cases that one should have a standard to go by, the deviations from which should be carefully noted. For this reason have chosen my adjectives with care as representing what to my mind is the type of the condition. And in closing I venture to ask the aid of those medical men who may happen to meet with such cases of albinism or of any of its varieties in the pursuit of their profession, that they may be good enough to help me to get into communication with the individuals they come across with a view to obtain the particulars of their family histories, assuring them that from all those who are good enough in this way to supply me with cases I shall feel myself the recipient of considerable personal favour. I am, Sirs, yours faithfully, A. R. GUNN

Physiological Department, University of Edinburgh, March 16th, 1907

\section{VACCINATION AND THE LONDON COUNTY COUNCIL ELECTION.}

To the Eators of THE LANCET.

SIRs,-Before the recent election the Vaccination Inquirer published answers received from 61 candidates in reply to a circular sent out by the National Antivaccination League. Candidates were asked definitely if they were in favour of abolishing the vaccination test for teachers and others who "honestly believe" vaccination to be injurious to health or unnecessary.

Since the election I have made an analysis which shows how the 61 candidates fared. 24 replied in the affirmative without definitely indicating whether they were pro- or antivaccinists, merely assenting to the principle of conscientious objection in their answers; of these nine were elected and 15 defeated. 26 declared themselves definitely pronounced anti-vaccinists; of these two were elected and 24 defeated. 11 declared themselves pro-vaccinists; of these eight were elected and three defeated.

These results must be very disappointing to the officials of the National Antivaccination League. Having regard to the declaration of the editor of the Vaccination Inquirer that "the occasion is one of the greatest importance to our cause," the blow must be rather disconcerting. One candidate evidently regarding his election an absolute certainty answered: "I shall certainly vote in the manner desired by the league." $\mathrm{He}$ was defeated. Another candidate answers : "I will not; I am convinced of the necessity of vaccination." He was at the head of the poll.

I am, Sirs, yours faithfully, Arthur Drury, M.B., C.M. Edin.

Halifax, March 25th, 1907.

\section{ON THE CONDITION OF THE BLOOD- VESSELS DURING SHOCK.}

\section{To the Editors of THE LANCET.}

SrRs, - In The LANCET of March 23rd, Dr. Leonard Williams stated an argument in which he invited me to find a fallacy, and with your permission I will point out two. Assuming the cardiac power to be constant, Dr. Williams said that when the vessels contracted the blood pressure rose and when they dilated the blood pressure fell. He asserted that the blood pressure in shock was invariably subnormal in any vessel in which it could be measured by the sphygma. nometer. He concluded that "the only possible deduction from these elementary facts is that the general state of the blood-vessels in shock is that of dilatation." 1

The first fallacy I would mention is that Dr. Williams omitted to say that the blood pressure is raised in the splenic vein in shock and he did not show why the deduction should not be arrived at that because of this rise of blood pressure the general state of the vessels must be one of contraction. Another most obvious fallacy in the argument is that the fall of blood pressure might be due to a dilatation of vessels which was not general but local. If Dr. Williams had remembered that it has been tanght for many years that the vascular changes in shock are due to a paralysis of the vessels in the splanchnic area he would, I think, have worded his argument differently.

I have already fully discussed these points in my papers, which you have been good enough to publish. I am, Sirs, yours faithfully,

Portman-street, W., March 25th, $1907 . \quad J O H N$ D. MALCOLM.

\section{MEDICAL LAW AND LIMITED COMPANIES.}

\section{Io the Editors of THE LANCET.}

SIRS, - In view of the publicity given to recent cases of evasion of the Medical and Dental Acts the following facts rnay show the need for amended legislation. A short time ago a patient came to me offering to apprentice his son with a view to his practising dentistry. When I inquired what hospital he would join the father said: "Hospital ? I shall not waste my money in fees nor my son's time when he can practise equally well without as long as he does not call himself a dentist." So I refused to take the premium or have anything to do with the case. No less than seven unregistered men have begun dental practice here in the last three years. It is useless to say that anyone can prosecute, for you cannot obtain evidence withou laying a "trap," and this is obnoxious to most Englishmen and prejudices the jury in favour of the defendant. If limited companies are to be tolerated, then they should be compelled to employ only registered men in the interests of the public. For to the man in the street anyone who extracts teeth is a dentist.

I am, Sirs, yours faithfully,

Torquay, March 25th, 1907. I. STRANGWAYS, L.D.S. Eng.

\section{MEDICAL MEN, MOTORS, AND LIGHTING OF VEHTCLES}

To the Editors of THE LANCET.

SIRS, - A very important Bill on the "Lighting of Vebicles" has passed the second reading in the House of Commons and has been referred to the Standing Committee on Law; its consideration will come on very shortly. It is very important that this Bill should be amended in order to secure a red light being carried at, or showing at, the rear of every vehicle used on the highways. Members of our own profession are especially interested in such an amendment. Some

1 The LaNCeT, March 23rd, 1907, p. 836 
vehicles, such as furniture vans, very often carry a small light in front placed in such a position that vehicles overtaking them have no warning until they are close on them. The country doctor using his motor in answer to an urgent summons in the night or early hours of the morning runs in constant danger from this cause, and every one of us must at some time or other have had narrow escapes owing to the absence of a light showing to the rear giving warning of a cart in front. Even before it was necessary that the motorcars should carry a light at the back for the purpose of Illuminating the number plate it was compulsory that they should show a red light at the back, and how it could be possible for legislators to pass a Bill compelling the fastest vehicles on the road to show a light at the back to prevent them being run into and yet allow farm carts and furniture vans and the like to use the same road and yet carry no light at the back at all has always been a puzzle to me. It would be a great help in securing such an amendment as $I$ have referred to if all medical motorists in the country would write to the Member of Parliament for their district pointing out the danger run by the doctor who has to be out at all hours of the night. I hope medical men will not treat this matter as though it were one of little concern to themselves. The passing of such an amendment would amply repay every medical man in the country for the small amount of time it would take to pen such a letter.

I am, Sirs, yours taithfully,

H. E. B. BRUCE-PORTER,

Honorary Secretary, Committee of Medical Men using Motors.

Grosvenor-street, W., March 22nd, 1907.

\section{"A DESCENDANT OF HUGH OLDHAM." To the Editors of THE LANCET.}

SIRs,-In referring in your issue of March 16th, p. 765, to the late Mr. C. J. Oldham, F.R.C.S., as a "descendant" of Hugh Oldham, Bishop of Exeter, you are exposing that prelate's memory to a good deal of obloquy. The vow of celibacy was enjoined on the clergy by Pope Hildebrand in or about A.D. 1000, whereas Hugh was not born before 1450 and died in 1520. That he died excommunicate is true, but this was not for a breach of the Papal decree but for a dispute on a building question with the powerful Abbot of Tavistock.

The late $\mathrm{Mr}$. Oldham did not claim to be a descendant, but a "kinsman," of Bishop Hugh; beyond that, if we are to judge by his bequests, he seems to have known little about him. For, though Hugh founded Manchester Grammar School, he was also founder of Netley Abbey, which the will ignores. Again, he founded Corpus Christi College, Oxford, in conjunction with Stephen Fox, Bishop of Winchester; but he was also, with the Bishop of Lincoln, joint founder of Brazenose College, Oxford, which is also ignored. As a matter of fact, no Oldham within the last 200 years ever has been able to prove direct connexion either with Bishop Hugh or with Bishop Richard Oldham, who in the thirteenth century was Abbot of Chester and Bishop of Sodor and Man.

I am, Sirs, yours faithfully,

March 17th, 1907.

Ralph S. Oldham.

** Our Manchester Correspondent was in error in using the word "descendant."-ED. L.

\section{TERTIARY SYPHILITIC FEVER.}

\section{To the Editors of THE LANCET.}

Sirs,-Dr. F. Parkes Weber has done well to draw attention to the occurrence of fever with syphilitic lesions, but I venture to suggest that he has not paid sufficient attention to the main points at issue. It may be true that many syphilitic lesions are accompanied by a varying degree of pyrexia-probably more often than is suspected-owing to the fact that the temperature is rarely taken for any con. siderable time in cases of syphilis. But this is a point of comparatively slight importance from the clinical point of view.

The importance of syphititic fever (I omit the word "tertiary" because there is no real pathological distinction either in time or nature between the so-called secondary and tertiary lesions) consists mainly in the diagnosis. Fever due to syphilis has been mistaken for typhoid fever, pneumonia, and tuberculous meningitis. Dr. J. D. Rolleston has recently drawn attention to this question with regard to typhoid fever. He has also reported a case in which early syphilitic brain symptoms were mistaken for enteric fever.

Fournier divides syphilitic fever into symptomatic and essential, the former accompanying the outbreak of cutaneous eruptions, \&c., the latter independently of them. It is to the latter class that Dr. Parkes Weber refers. Fournier describes a continuous type and an intermittent type, the former of which he designates syphilitic typhose (typhosis). He also points out that such cases of "syphilitic typhosis" may be mistaken for enteric fever, and says that the chief points in which syphilitic typhosis differs from enteric fever are the absence of the characteristic temperature chart of enteric fever, the enlarged spleen, iliac pain, dry, glazed tongue, and delirium. The blood is also negative to Widal's agglutination reaction. It would therefore appear that, however interesting "syphilitic fever" may be from a pathological point of view, its main importance lies in its diagnosis from enteric fever, meningitis, and pneumonia. I am, Sirs, yours faithfully,

New Cavendish-street, W., March 18th, 1907.

$$
\text { C. F. Marshall. }
$$

\section{To the Editors of THE LANCET.}

SIRS,- It does not appear to be generally known that the occurrence of fever in syphilis was mentioned by some of the earliest writers on the disease. Having recently ${ }^{1}$ had occasion to peruse the early literature of syphilis I have thought that the following notes might be of interest to some of your readers. Long before John Hunter, ${ }^{2}$ to whom Dr. Parkes Weber alludes in his interesting paper, ${ }^{3}$ the syphilographers of the sixteenth century, whose works are contained in the collection of Luisinus, had spoken of the existence of fever in the Morbus Gallicus. According to Fracastor, ${ }^{4}$ to whom syphilis owes its name, a slight degree of fever was an occasional though rare evenù: "Quandoque et febricula quædam concomitabatur, sed raro." Fallopius's words are similar 5 : "Solet aliquando febricula adjungi ob fervorem circa viscera ferventia. Sed hoc raro fit." Petronius wrote to the same effect ${ }^{6}$ : "His nunc aberat, nunc adjuncta febris erat." Haschard 7 also speaks of a "lenis febricula" as one of the early symptoms of the disease. Rondelet, the original of Rabelais's Rondibilis, stated that "some after receiving the infection are seized with fevers and falling into profuse sweats part of the venom is discharged thereby." 8

According to Vigo ${ }^{9}$ fever was a late symptom. "Ultimo loco vidimus febriculam oriri quæ tot prænominatis malis hominem ad ultimum ejus diem conducebat." Ulrich von Hutten, ${ }^{10}$ one of the most interesting figures in the history of the Reformation, and himself a sufferer from the new disease, also stated that "phthisis" was a sequel. Ambroise Paré ${ }^{11}$ also reckoned fever among the late phenomena: "Autres demeurent asthmatiques et hectiques avec une fièvre lente, et meurent tabides et desseichez." Brassavolus ${ }^{12}$ took a less serious view of protracted fever: "Lentæ febres, ac longæ cum morbo Gallico futuram hecticam minime significant. Infinitos enim vidi, qui in tales incidere febres ... tamen hectici non evasere, imo Gallico affectu curato, et etiam per existentia, febris 'ipsa una curata est, ac abivit." Of subsequent writers prior to John Hunter, Daniel Turner deserves special mention. In his work on syphilis which seems to have fallen into ill-merited oblivion numerous references are made to the existence of fever in syphilis. ${ }^{13}$ Then, as now, patients supposed to be suffering with phthisis were really the subjects of venereal infection, and when almost reduced to the last extremity owed their salvation to a correct diagnosis and the exhibition of mercury.

How hopeful a view Turner took of syphilitic fever is well shown by the following quotation: "Of all the several sorts of consumptions ...... I should more willingly encounter the

1 Medical Press and Circular, March 20th, 1907, in which I have recorded two cases of syphilis simulating typhoid fever.

A Treatise on the Venereal Disease, first edition, 1786 , p. 300. 3 The LanceT, March 16th, 1907, p. 728

4 Luisinus: Aphrodisiacus sive de Lue Venerea continens omnia quacunque de hac re sunt ab omnibus medicis conscripta, Lug. Bat., 1728 , p. 199

5 Ibid., p. $780 . \quad 6$ Ibid., p. $325 . \quad 7$ Ibid., p. 930. 8 Daniel Turner: Aphrodisiacus, 1736 (abridged English version of Luisinus).

$$
\begin{aligned}
& 9 \text { Ibid., p. } 450 . \\
& 10 \text { Ibid., p. } 279 . \\
& 12 \text { Luvres, Lyon, 1641, p. 444. }
\end{aligned}
$$

13 A Practical Dissertation on the Venereal Disease, 1724, pp. 261, $267,278,304$. 